HELMINTHOLOGIA, 57, 2: 120 - 128, 2020

\title{
The mouse bile duct tapeworm, Hymenolepis microstoma in free-living small mammals in Slovakia: occurrence and genetic analysis
}

\author{
J. JAROŠOVÁ1, V. ŠNÁBEL' 1 , S. CAVALLERO², G. CHOVANCOVÁ ${ }^{3}$, Z. HURNÍKOVÁ1 , D. ANTOLOVÁ1,*

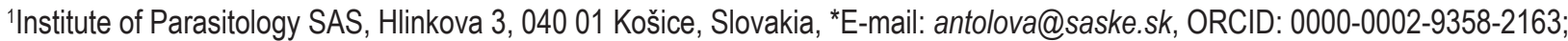 \\ ${ }^{2}$ University of Rome, P. le Aldo Moro 5, 00185 Rome, Italy; ${ }^{3}$ Research Station and Museum of the Tatra National Park, \\ Tatranská Lomnica, Slovakia
}

Article info

Received December 19, 2019 Accepted February 17, 2020

\section{Summary}

The mouse bile duct tapeworm Hymenolepis microstoma, is a potentially zoonotic species with a wide variety of reported definitive hosts of rodent genera. In the present study the occurrence of $H$. microstoma in free-living small mammals in selected areas of Slovakia and the retrospective analysis of epidemiological data published in Slovakia were performed. Hymenolepis microstoma was detected in two animal species, the common shrew (Sorex araneus) and the European hamster (Cricetus cricetus) of 186 small mammals examined from two ecosystems, urban and natural ecosystem of national park. No mention about the presence of this parasite in Slovakia in the past was found following a bibliographical search. Partial sequences of the nuclear paramyosin gene showed the shrew isolate placed in a subclade together with $\mathrm{H}$. microstoma from Portugal, with high bootstrap value for its differentiation from the sister species Hymenolepis nana. Similarly, the analysis of the nuclear ribosomal ITS region placed the hamster isolate in the cluster composed of $\mathrm{H}$. microstoma from Australia, Spain and Portugal. The Slovak isolate was the most distinctive sample among available $\mathrm{H}$. microstoma, differing in $1.4-1.9 \%$ of nucleotides from the remaining isolates. The difference (seven of 17 nucleotide positions) was partially due to indel polymorphisms associated with two and five nucleotides. To our knowledge, these are the first reports of $H$. microstoma in Central Europe and also the first record of infection in the common shrew. A recently indicated zoonotic potential of $H$. microstoma along with a possibility of its direct transmission between animals and/or humans without the need of intermediate hosts pose a public health concern in contaminated areas of Slovakia. The use of molecular techniques may substantially facilitate more thorough understanding of the epidemiological situation of $H$. microstoma and related tapeworms in various ecosystems of the country.

Keywords: Hymenolepis microstoma; Small mammals; Occurrence; Genetic analyses; Slovakia

\section{Introduction}

Among tapeworms belonging to the genus Hymenolepis, three species are medically relevant and are commonly found worldwide in sites where murid rodents occur: Hymenolepis nana (Siebold, 1852), Hymenolepis diminuta (Rudolphi, 1819), and Hymenolepis microstoma (Dujardin, 1845) Blanchard, 1891 (Cunningham \& OIson, 2010). Hymenolepis (= Rodentolepis) microstoma, the mouse bile duct tapeworm, has a wide variety of reported definitive hosts of rodent genera as mice (Hopkins et al., 1977), rats (Goodall, 1972), hamsters (Bogh et al., 1986), voles (Litchford, 1963), and gerbils (Schmidt, 1986). A zoonotic potential of this tapeworm

\footnotetext{
* - corresponding author
} 
was indicated by a single report in which mixed infections of $H$. nana and $H$. microstoma were identified in four humans from a remote region of Western Australia (Macnish et al., 2003). H. microstoma is recognized as requiring an appropriate tenebrionid grain beetle or other insect as intermediate host (originated mostly from Tribolium and Tenebrio genera), in which the eggs develop into cysticercoids after ingestion (Bogh et al., 1986; Smyth \& Wakelin, 1994). Nevertheless, the feasibility of a direct life cycle in immunodeficient mice has also been demonstrated for the mouse bile duct tapeworm (Andreassen et al., 2004).

$H$. microstoma has attracted considerable attention since it was first described by Dujardin in 1845. In 1891, Blanchard relocated the species to the genus Hymenolepis and provided a more detailed description of the species. Since 1950s, $H$. microstoma is being commonly used as an experimental model. Due to its easy maintenance in the laboratory in mice host and short life cycle, $H$. microstoma has been established as a preferable model to both $H$. nana and $H$. diminuta, the maintenance of which is more costly (Clark, 2013). Moreover, the mouse bile duct tapeworm is one of the four tapeworm species having its complete genome assembled and characterized (Cunningham \& Olson, 2010; Tsai et al., 2013). Although adult $H$. microstoma specimens may be differentiated based on morphological characteristics and predilection site (Baer \& Tenora, 1970; Czaplinski \& Vaucher, 1994), in some cases these characteristics are difficult to use, especially when dead animals are sampled (e.g. in national parks) and the carcasses (along with their intestinal parasites) are in some stage of decay. Furthermore, a variety of other hymenolepidid species, morphologically similar to $H$. microstoma, can potentially infest free-living small mammals (Riebold et al., 2019). Thus, the use of molecular tools, especially in cases when identification via morphology is ambiguous, is essential for identifying and classifying species (Peniche et al., 2017). The study was designed to survey the occurrence of $H$. microstoma in free-living small mammals in selected areas of Slovakia and to conduct a retrospective analysis of epidemiological data published in Slovakia. In addition, the genetic typing at species level of collected isolates was carried out.

\section{Materials and Methods}

Collection of small mammals and isolation of tapeworms

Small mammals were obtained from two different ecosystems, specifically from the protected area of the Tatra National Park (TANAP) and the surroundings situated in north Slovakia and from the urban area of Košice city and Rozhanovce village, in southeast of Slovakia.

In Tatra National Park and its surroundings, small mammals were trapped during 2015 and 2016 within the zoological survey carried

Table 1. List of small mammal species collected from two localities in eastern and northern Slovakia.

\begin{tabular}{|c|c|c|}
\hline Locality & Animal species & $\begin{array}{c}\text { No. of tested } \\
\text { individuals }\end{array}$ \\
\hline \multirow{12}{*}{$\begin{array}{l}\text { Tatra National Park } \\
\text { and surroundings }\end{array}$} & Brown rat (Ratus norvegicus) & 1 \\
\hline & House mouse (Mus musculus & 12 \\
\hline & Striped field mouse (Apodemus agrarius) & 4 \\
\hline & Yellow-necked mouse (Apodemus flavicollis) & 21 \\
\hline & Common shrew (Sorex araneus) & 38 \\
\hline & Eurasian pygmy shrew (Sorex minutus) & 14 \\
\hline & Alpine shrew (Sorex alpinus) & 1 \\
\hline & Mediterranean water shrew (Neomys anomalus) & 1 \\
\hline & Common vole (Microtus arvalis) & 1 \\
\hline & Field vole (Microtus agrestis) & 5 \\
\hline & Bank vole (Clethrionomys glareolus) & 26 \\
\hline & European mole (Talpa europaea) & 4 \\
\hline \multirow{14}{*}{$\begin{array}{l}\text { Košice city and } \\
\text { Rozhanovce village } \\
\text { and surroundings }\end{array}$} & Brown rat (Ratus norvegicus) & 21 \\
\hline & House mouse (Mus musculus) & 7 \\
\hline & European hamster (Cricetus cricetus) & 2 \\
\hline & Eurasian harvest mouse (Micromys minutus) & 1 \\
\hline & Hazel dormouse (Muscardinus avellanarius) & 1 \\
\hline & Striped field mouse (Apodemus agrarius) & 2 \\
\hline & Yellow-necked mouse (Apodemus flavicollis) & 2 \\
\hline & Lesser shrew (Crocidura suaveolens) & 5 \\
\hline & Eurasian pygmy shrew (Sorex minutus) & 3 \\
\hline & Common shrew (Sorex araneus) & 2 \\
\hline & Common vole (Microtus arvalis) & 4 \\
\hline & European pine vole (Microtus subterraneus) & 7 \\
\hline & European mole (Talpa europea) & 1 \\
\hline & TOTAL & 186 \\
\hline
\end{tabular}


out after the wind storm in November 2004 or found dead by workers of Research Station and Museum of TANAP or by inhabitants and visitors of national park.

Wooden nutrient traps placed in a square grid (mesh size $15 \times 15$ $\mathrm{m}$ ) on square dimensions of $75 \times 75 \mathrm{~m}$ were used to capture small mammals in Stará Lesná, Tatranská Lomnica, Tatranské Matliare, Hrebienok, Smokovec pod Hrebienkom, Spišská Sobota or their close vicinity. For the collection of protected animal species, an "Exception for the approach outside of tourist trails, and for the collection, holding and relocation of dead protected animal species for museum processing and scientific research" was obtained from the Ministry of Environment of the Slovak Republic (MŽP SR 498/2018-6.3.).

In TANAP and its surroundings a total of 128 small mammals were sampled. In Košice city and Rozhanovce village and the vicinity, 58 synanthropic small mammals found dead (after road accidents, poisoning etc.) were collected (Table 1).

Small mammals were autopsied; intestinal tract was isolated, opened and searched for the presence of tapeworms. Whole isolated tapeworms or their parts were individually placed into the $1.5 \mathrm{~mL}$ microcentrifuge tubes and used for molecular analyses. Unfortunately, due to the poor post-mortem status of carcasses with the developing decay, it was impossible to characterize the tapeworms by morphological features.

\section{Molecular analyses}

Individual tapeworms (or their parts) were analysed by PCR-derived methods. For this purpose, genomic DNA was isolated by DNeasy tissue kit (Qiagen, Hilden, Germany) according to the manufacturer's instructions. PCR reactions were performed using 5x FIREPoI $囚$ Master Mix Ready to Load (SOLIS Biodyne, Estonia). The first internal transcribed spacer region (ITS1) with adjacent partial subunits $(18 S, 5.8 S)$ of ribosomal DNA and the nuclear gene coding for paramyosin (pmy) gave satisfactory DNA profiles in single isolates allowing to derive their relationships with other hymenolepidids using GenBank ${ }^{\circledR}$ deposited sequences. Primers amplifying the ITS1 region (F3, R3) and running conditions were those previously described in Macnish et al. (2002). The final PCR product included $22 \mathrm{bp}$ of the $18 \mathrm{~S}, 587 \mathrm{bp}$ of the ITS1 and $23 \mathrm{bp}$ of the $5.8 \mathrm{~S}$ (in total $632 \mathrm{bp}$ ). For the pmy amplification, a nested PCR approach was employed according to the protocol provided in the above study. Using the external set of primers (Ext-F, Ext-R) a $700 \mathrm{bp}$ product was first amplified. The internal set of primers then amplified DNA template from the primary PCR reaction, resulting in a 617 bp product for $H$. microstoma. Compositions of primers and running conditions for primary and secondary nested PCRs were those outlined in Macnish et al. (2002), except that 40 cycles were carried out in both reactions.

\section{Phylogenetic analyses}

The consensus sequences were screened against the GenBank® database using the BLAST algorithm. For the ITS1 region, nucle- otide sequences were aligned using the WebPrank global alignment tool (Löytynoja \& Goldman, 2010) to better identify structural constraints of transcribed but not translated regions that include several indels. For the pmy gene, sequences were aligned using the Clustal Omega tool for multiple sequence alignment (Sievers et al., 2011). Phylogenetic trees were constructed by MEGA7 software (Kumar et al., 2016), using the neighbor-joining (NJ) method. Evolutionary distances were computed using the Tamura-3-parameter model of nucleotide substitutions, taking into account differences in transitional and transversional rates and $\mathrm{G}+\mathrm{C}$-content bias (Tamura, 1992).

\section{Retrospective bibliographical search on Hymenolepis microstoma} occurrence

To retrospectively verify records on the occurrence and distribution of $H$. microstoma in Slovakia over the last decades, a key inclusion criterion was a comprehensive 'Synopsis of Cestodes in Slovakia', covering detailed data on hosts, localities and occurrences of tapeworms in small mammals and birds in Slovakia since 1955, and published during 1993 - 1999 as a series of articles, two of which provided records on the family Hymenolepididae (Hanzelová et al., 1995; Hanzelová \& Ryšavý, 1996). In addition to this checklist, in particular for covering the synoptical period onwards, a bibliographical search of available literature in scientific databases (PubMed, ISI Web of Knowledge, SCOPUS, ScienceDirect and Google Scholar) was conducted to find studies reporting the occurrence of $H$. microstoma in small mammals in Slovakia. The following key terms and their combinations were used for the database searches: Hymenolepis microstoma, Rodentolepis microstoma, Vampirolepis microstoma, Slovakia, Slovak Republic and Czechoslovakia. Besides, the books, journals and annual reports deposited in the Library of the Institute of Parasitology of Slovak Academy of Sciences were searched.

\section{Ethical Approval and/or Informed Consent}

The research related to animals has been complied with all the relevant national regulations and institutional policies for the care and use of animals.

\section{Results}

Occurrence of Hymenolepis microstoma in small mammals in Slovakia

From a total of 186 examined animals collected from the two localities in eastern and northern Slovakia, in 32 small mammals hymenolepidid tapeworms were detected. All individual tapeworms or their parts were examined molecularly, in scope of which the ITS1 and paramyosin markers were amplified. Ten isolates gave positive PCR signal with either DNA region and were subsequently sequenced. As a result, two isolates from two animal species coming from different ecosystems were identified as $\mathrm{H}$. microstoma. 


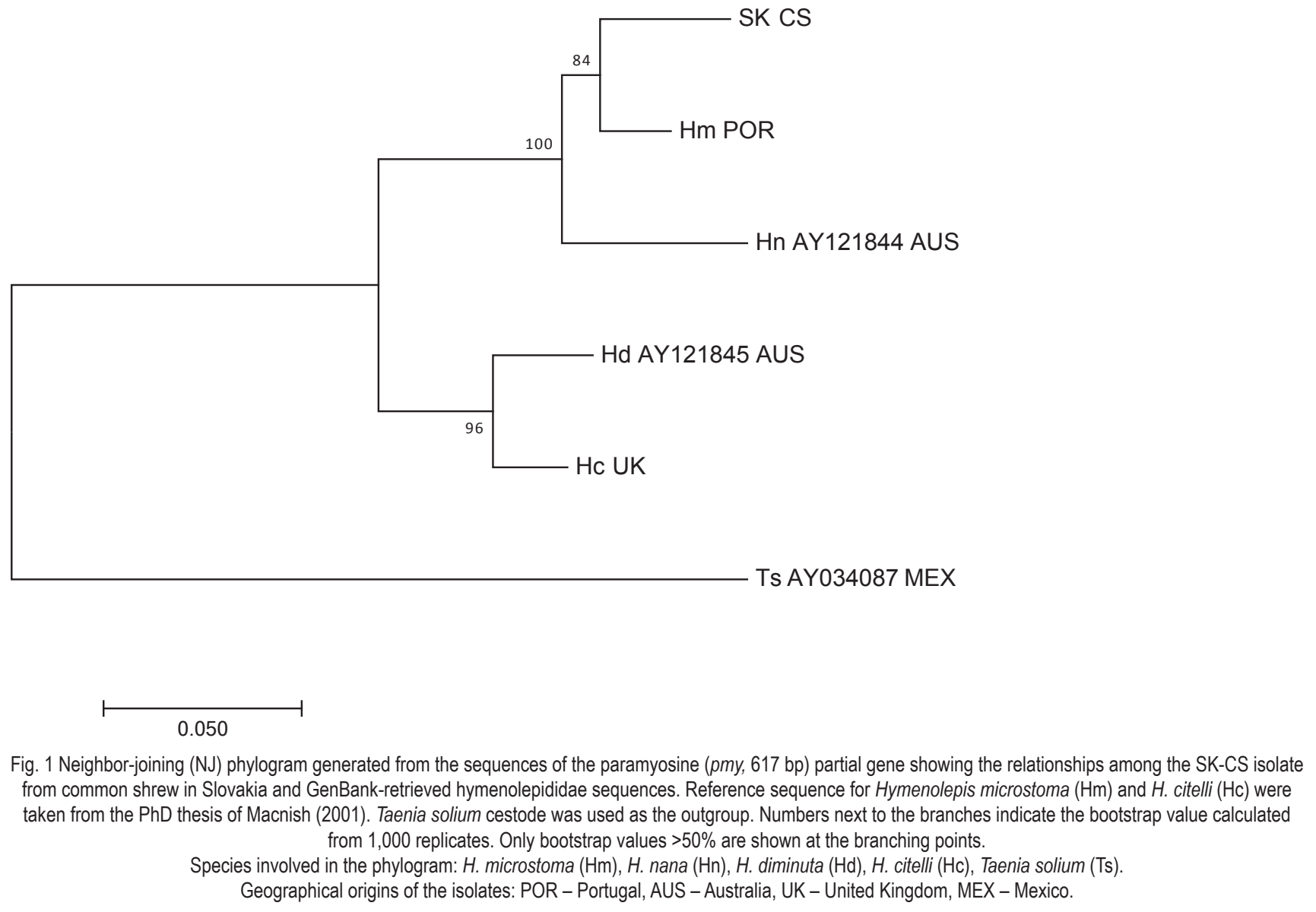

The first isolate (assigned as SK-CS) originated from the common shrew (Sorex araneus) caught in surroundings of Tatranské Matliare village (TANAP, north Slovakia). The second isolate (assigned as SK-EH) was obtained from the European hamster (Cricetus cricetus), which was found dead in an urban ecosystem of Košice city in south-east of Slovakia.

Gene sequences obtained in the study were deposited in GenBank® under accession numbers MN617852 for a SK-CS isolate (common shrew, Tatranské Matliare) and MN620506 for a SK-EH isolate (European hamster, Košice).

Genetic analyses of Hymenolepis microstoma isolates

A consensus sequence of $617 \mathrm{bp}$ was obtained from the amplification of the partial pmy gene in the SK-CS isolate. A two-base-deletion at positions 506 and 507 was identified in SK-CS compared to other Hymenolepis spp. with available sequences, $H$. nana, $H$. microstoma, $H$. diminuta and $H$. citelli. In the N-J phylogram, the SK-CS sample clustered together with $H$. microstoma and $H$. nana (100 \% bootstrap support), in the subclade composed of SK$\mathrm{CS}$ and $\mathrm{H}$. microstoma that also received a high bootstrap value (84 \%) for its differentiation from H. nana (Fig. 1). The percentage nucleotide difference between the $H$. microstoma sequence derived from a Portuguese mouse isolate (the sequence provided by Macnish, 2001) and the SK-CS isolate was $4.86 \%$.

The analysis of the ITS region and the adjacent rRNA partial genes $(18 S, 5.8 S)$ of the total size of 632 bp showed that the SK-EH isolate was grouped with seven $\mathrm{H}$. microstoma specimens (Australia, Spain, Portugal) in the highly bootstrapped cluster (100\%), and clearly differentiated from the adjacent $H$. nana cluster (phylogram shown in Fig. 2). Interestingly, SK-EH constituted the most distinct sample within the $H$. microstoma assemblage, differing in $1.4-$ $1.9 \%$ of nucleotides from the remaining samples. Ten nucleotide substitutions, five-base deletion (-CGTTG) at nucleotide positions $271-275$ and two-base insertion (+CA) at positions $107-108$, accounted for this difference. In the rest of $H$. microstoma isolates only single-, two-, and three-nucleotide polymorphisms were detected although the samples originated from distinct geographical locations (Australia and southern Europe). Furthermore, indels were recorded only in SK-EH among the $\mathrm{H}$. microstoma representatives. The observed deletion (-CGTTG) is responsible for the absence of arginine in the corresponding protein sequence. 


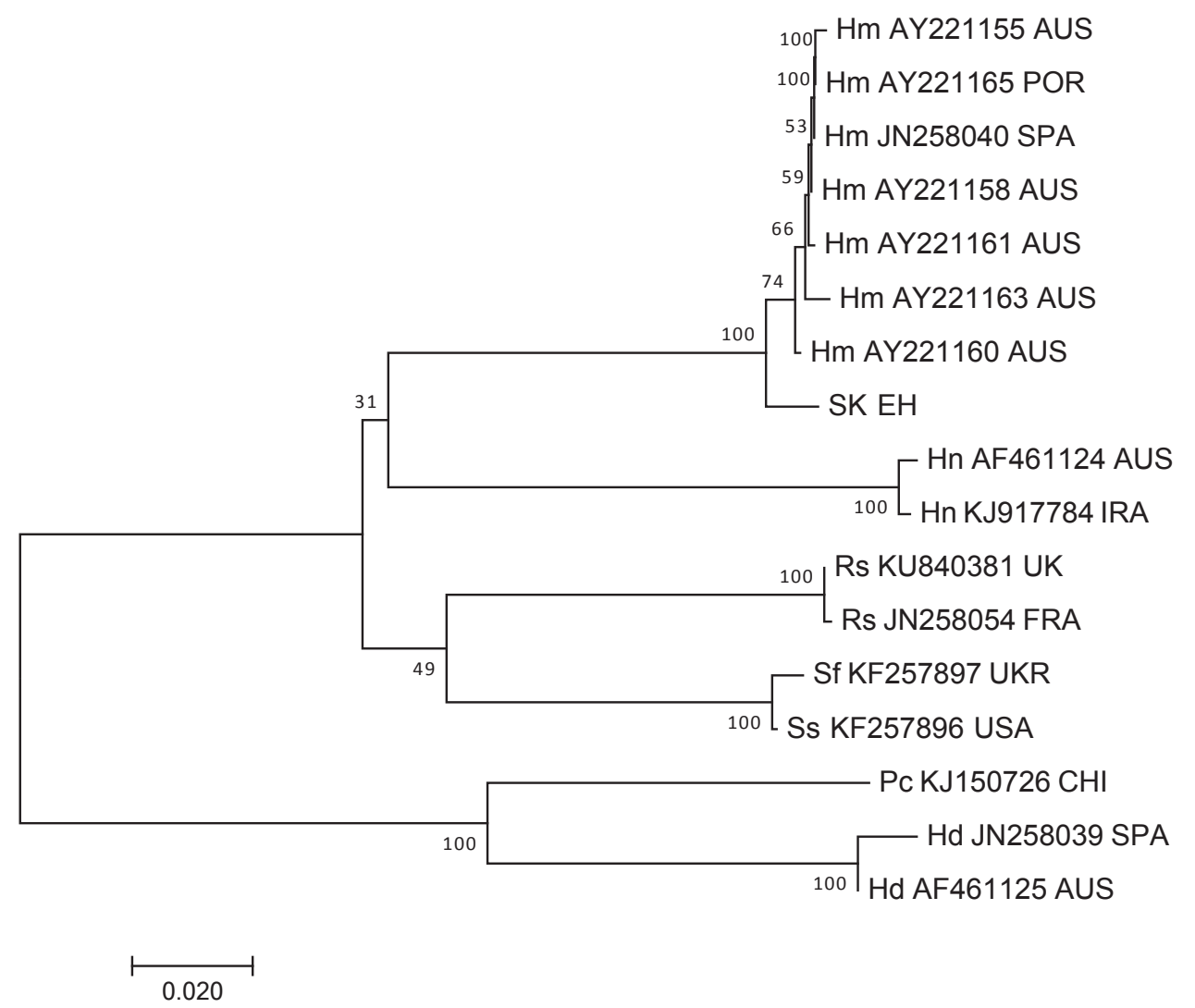

Fig. 2 Neighbor-joining (NJ) phylogram generated from the sequences of the ribosomal internal transcribed spacer (ITS1, 632 bp) showing the relationships among SK-EH isolate from European hamster in Slovakia and GenBank-retrieved hymenolepididae sequences. Numbers next to the branches indicate the bootstrap value calculated from 1,000 replicates. Only bootstrap values $>50 \%$ are shown at the branching points.

Species involved in the phylogram: Hymenolepis microstoma $(\mathrm{Hm}), H$. nana $(\mathrm{Hn})$, H. diminuta $(\mathrm{Hd})$, Rodentolepis straminea (Rs), Pseudoanoplocephala crawfordi $(\mathrm{Pc})$, Staphylocystis furcata (Sf), Staphylocystis schilleri (Ss). Geographical origins of the isolates: AUS - Australia, POR - Portugal, SPA - Spain, IRA - Iran, UK - United Kindom, UKR - Ukraine, FRA - France, USA - United States of America, CHI - China.

Retrospective analysis of epidemiological data published in Slovakia

The search of scientific databases has not shown any publication reporting the presence of Hymenolepis (Rodentolepis) microstoma in the territory of Slovakia in the past. Likewise, no record on this tapeworm was included in the 'Synopsis of Cestodes in Slovakia', confined to the period from 1955 to 1996 in small mammals, in the two articles involving findings of 114 taxa belonging to the family Hymenolepididae in Slovakia (Hanzelová et al., 1995; Hanzelová \& Ryšavý, 1996).

Likewise, no mention about the presence of $H$. microstoma was found within the retrospective search of annual reports of the Institute of Parasitology SAS, reflecting the occurrence of helminths in different species of rodents, soricimorphs and small mammals from a variety of areas in Slovakia. Specifically, H. microstoma was not recorded in brown rats (Rattus norvegicus) from 52 districts of Slovakia in the period of 1956 - 1957 (Mituch, 1958), in 936 soricimorphs from 147 localities of Slovakia in $1958-1960$ (Mituch, 1961), in 2,302 rodents and 1,040 soricimorphs from the territory of TANAP in 1966 - 1970 (Mituch, 1970), in 425 rodents and 98 soricimorphs from the Slovak territory of the Carpathian arc in 1986 - 1987 (Mituch et al., 1987), and in 55 soricimorphs and 245 rodents from the surroundings of Košice city in $1985-1988$ (Gajdoš, 1990).

\section{Discussion}

Although $\mathrm{H}$. microstoma was not recorded to date in any study of intestinal parasites of small mammals conducted in the territory of Slovakia, the present research documented its occurrence in the country. The parasite was recorded in two animals, in the common shrew (Sorex araneus) and in the European hamster (Cricetus cricetus), in two geographically distinct sites and ecosystems of Slovakia.

To our knowledge, these are also the first documented reports H. microstoma in Central Europe, considering that no data about its occurrence are available in the literature including records deposited in the Host-Parasite database of the Natural History Museum (Gibson et al., 2005). As the parasite was not included in the checklist 'Synopsis of Cestodes in Slovakia', encompassing 
records from a number of local and broader surveys in Slovakia during 1955 - 1996 (Hanzelová \& Ryšavý, 1996), it is likely that the mouse bile duct tapeworm was introduced into the Slovak territory over the last two decades.

The parasite was found close to Tatranské Matliare village in the vicinity of the protected area of the Tatra National Park in a common shrew (Sorex araneus). As far as we are aware, the present study also provides the first record of $H$. microstoma infection in $S$. araneus, which is one of the most common and abundant woodland micromammals in different types of forests (Mitchell-Jones et al., 1999; Rychlik, 2000), whose presence has also been confirmed in $90.3 \%$ of the area of Slovakia (Krištofík et al., 2012).

Two H. microstoma-specific DNA profiles (assigned as SK-CS and SK-EH) were identified among 10 hymenolepidid isolates examined with pmy and ITS-1 markers. In the partial pmy gene, the shrew isolate (SK-CS) has formed the subgroup with $H$. microstoma, thus differentiating this couple from the close $H$. nana with whom one of two main clades in the $\mathrm{NJ}$ tree inferred from Hymenolepis-deposited sequences was formed. The percentage nucleotide difference between the SK-CS isolate and the H. microstoma sequence obtained from a Portuguese mouse isolate (Macnish, 2001) was $4.86 \%$, which is a relatively high value, comparable to the interspecific nucleotide difference (4.21\%) between $\mathrm{H}$. diminuta and $H$. citelli in the screened pmy region. Nevertheless, given that we have found no record of the $H$. microstoma grouping with any other species when $\mathrm{H}$. nana was present as the closest relative in phylograms inferred from nuclear and/or mitochondrial data, and the strong genetic cohesiveness between the $\mathrm{H}$. microstoma reference and our sample (their subclade received the bootstrap value of $84 \%$ ), the classification of the studied isolate as belonging to $H$. microstoma is highly plausible.

After analysis of the nuclear ribosomal ITS region, the hamster isolate (SK-EH) originated from an urban ecosystem in south-east Slovakia clustered with $\mathrm{H}$. microstoma specimens from the two continents (Europe, Australia). Interestingly, SK-EH appeared to be the most distinctive sample among $\mathrm{H}$. microstoma examined so far in ITS-1, differing in $1.4-1.9 \%$ of nucleotide bases from the remaining isolates that markedly exceeded the value of the average intercontinental base difference measured between isolates from southern Europe and Australia (0.14\%). The difference was partially due to the two indel polymorphisms associated with two and five nucleotides, respectively, the latter of which accounted for the absence of arginine in the protein composition. It has been found that especially during starvation, flatworm parasites including $\mathrm{H}$. diminuta develop enzymes to synthesize arginine and urea, offering an advantage for osmoregulation and serving as effective nutrients in the fasting state (Campbell, 1963; Mohamed et al., 2005). Nevertheless, some studies have suggested that arginine is not necessarily an essential amino acid for a variety of invertebrates including flatworms if ornithine can be synthesized (Campbell \& Speeg, 1968; Tielens \& van Hellemond, 2005).

With regard to the three most important Hymenolepis spp., phy- logenetic analysis of nuclear targets herein employed corroborated that representatives of $H$. nana and $H$. microstoma form a strongly supported clade with respect to $H$. diminuta, which may have diverged from the common ancestral line earlier. Similar results with respect to the systematic position of these species were also obtained by other mitochondrial (cox1) and nuclear (ITS2, 18S) evidences (e.g. Okamoto et al., 1997; Macnish et al., 2002; Olson et al., 2003; Sharma et al., 2016). Besides, studies on immunobiological characteristics and cysticercoid development from eggs suggested that $H$. microstoma is more similar to $H$. nana than to $H$. diminuta (Voge, 1964; Ito et al., 1988).

In previous surveys, $\mathrm{H}$. microstoma was genetically identified in two consecutive studies by Macnish et al. $(2002,2003)$ in mice (Mus musculus) from Portugal, Australia and the United Kingdom, and in humans from Australia. In the Canary Islands (Spain), Foronda et al. (2011) detected H. microstoma in $10.8 \%$ of the examined house mice (Mus musculus) and in $0.3 \%$ of black rats (Rattus rattus), but none of 13 brown rats (Rattus norvegicus) was positive. In twelve cestodes collected from house mice (Mus musculus) in Lima (Peru), morphologically and genetically (cox1 mt gene) categorized as $\mathrm{H}$. microstoma, lower genetic variability between specimens from Peru and Spain compared to Japan indicated that the parasite was introduced into Peru from a European country (Gomez-Puerta et al., 2018). A close phylogenetic match to $H$. microstoma was also determined in the tapeworm derived from captive dormouse (Muscardinus avellanarius) in the United Kingdom (Peniche et al., 2017).

The dwarf tapeworm $H$. nana is the only cestode recognized as not requiring an intermediate host to develop into maturity under natural conditions (Dovč et al., 2017). The potential capability of the direct life cycle for $\mathrm{H}$. microstoma (as another common feature with $H$. nana) has been discussed in the literature in the past (Skrjabin \& Kalantarian, 1942; Macnish et al., 2003), and later evidenced in immunocompromised mice by Andreassen et al. (2004) who showed that oncospheres penetrated the intestinal tissues and developed into cysticercoids and subsequently into the adult stage in the bile duct and duodenum when infected with parasite eggs. It is therefore presumed that the development of patent infections of $H$. microstoma in humans could more likely occur in immunocompromised individuals. Malnourishment, type II diabetes, alcoholism, cancer, HIV-infection, immunosuppressive therapy, etc. (e.g. Kontogiorgi et al., 2013; Kumari et al., 2014) are factors contributing to depression of the immune system and may enhance the development of infections with parasites such as $H$. microstoma in humans.

To date, the majority of published surveys in free-living and domestic small mammals reported the occurrence of hymenolepidid tapeworms based on coprological examination (Jarošová et al., 2020). Due to striking morphological similarity of the eggs of $H$. microstoma and $H$. nana that are difficult to distinguish by morphology alone (Fitzgerald et al., 1970; Macnish, 2001), it is possible that some infections of $H$. microstoma in animals and humans 
may have been previously misdiagnosed as $H$. nana (Whary et al., 2015; Riebold et al., 2019). In addition, infection in humans may have been underdiagnosed due to sporadic or reduced egg shedding that was documented in $H$. nana, $H$. diminuta and $H$. citelli in response to factors such as the quality and quantity of the host diet (Kennedy, 1983; Schantz, 1996) and can occur also in H. microstoma.

A recently indicated zoonotic potential of $H$. microstoma (Macnish et al., 2003) along with a possibility of its direct transmission between animals and/or humans without the need for intermediate hosts pose a public health concern in contaminated areas of Slovakia. In the present study, the use of molecular techniques has enabled identification of the mouse bile duct tapeworm circulating in the two animal populations of Slovakia and will greatly facilitate a more thorough understanding of the epidemiological situation of $H$. microstoma and related tapeworms in various ecosystems of the country in the future.

\section{Conflict of Interest}

Authors state no conflict of interest

\section{Acknowledgement}

The work was financially supported by the Science Grant Agency VEGA project No. 2/0107/20 and by the Research \& Development Operational Program funded by ERDF "Environmental protection against parasitozoonoses under the influence of global climate and social changes", code ITMS 26220220116 (0.3).

\section{References}

Andreassen, J., Ito, A., Ito, M., Nakao, M., Nakaya, K. (2004): Hymenolepis microstoma: direct life cycle in immunodeficient mice. J. Helminthol., 78(1): 1 - 5

BaER, J.G., TenORA, F. (1970): Some species of Hymenolepis (Cestoidea) from rodents and from primates. Acta Sci. Nat. Brno, 4(9): $1-32$

Blanchard, R. (1891): Histoire Zoologique et Médicale des Téniadés du genre Hymenolepis Paris, Weinland, 112 pp.

Bogh, H.O., Christensen, J.P.B., Andreassen, J. (1986): Complement-mediated lysis in vitro of newly excysted tapeworms: Hymenolepis diminuta, Hymenolepis microstoma, Hymenolepis nana and Hymenolepis citelli. Int. J. Parasitol., 16(2): 157 - 161. DOI: 10.1016/0020-7519(86)90100-1

CAmpBell, J.W. (1963): Urea formation and urea cycle enzymes in the cestode, Hymenolepis diminuta. Comp. Biochem. Physiol., 8(1): 13 - 27. DOI: 10.1016/0010-406x(63)90065-3

Campbell, J.W., Speeg, K.V. JR. (1968): Arginine biosynthesis and metabolism in terrestrial snails. Comp. Biochem. Physiol., 25(1): 3 - 32. DOI: 10.1016/0010-406x(68)90911-0

Clark, P.R., Ward, W.T., Lang, S.A., Saghbini, A., Kristan, D.M.
(2013): Order of Inoculation during Heligmosomoides bakeri and Hymenolepis microstoma Coinfection Alters Parasite Life History and Host Responses. Pathogens, 2(1): 130 - 152. DOI: 10.3390/ pathogens2010130

Cunningham, L.J., OLson, P.D. (2010): Description of Hymenolepis microstoma (Nottingham strain): a classical tapeworm model for research in the genomic era. Parasit. Vectors, 3: 123. DOI: 10.1186/1756-3305-3-123

Czaplinski, B, Vaucher, C. (1994): Family Hymenolepididae Ariola, 1899. In: Khalil L.F., Jones A., Bray R.A. (Eds) Keys to the Cestode Parasites of Vertebrates. Wallingford, UK, CAB International, pp. $595-663$

Dovč, A., Gregurić Gračner, G., Tomažıč, I., Vlahović, K., Pavlak, M., Lindtner, Knific, R., Kralu, K., Stvarnik, M., Vergles Rataj, A. (2017): Control of Hymenolepis nana infection as a measure to improve mouse colony welfare. Acta Vet. Hung., 65(2): 208 - 220. DOI: 10.1556/004.2017.021

Dujardin, M.F. (1845): Histoire Naturelle des Helminthes ou vers intestinaux, $680 \mathrm{pp}$.

Fitzgerald, M.D., Jones, A.W., Tan, B.D. (1970): Hymenolepis nana and $H$. microstoma: oncospheral hook orientation. Trans. Am. Microsc. Soc., 89(2): $300-304$

Foronda, P., López-González, M., Hernández, M., Haukisalmi, V., FeLIU, C. (2011): Distribution and genetic variation of hymenolepidid cestodes in murid rodents on the Canary Islands (Spain). Parasit. Vectors, 4: 185. DOI: 10.1186/1756-3305-4-185

GAJdoš, O. (1990): Helmintocenózy dominantných a subdominanných stavovcov v oblasti ZOO Košice [Helminthocenoses of dominant and subdominant vertebrates in area of ZOO Košice]. PhD thesis. Institute of Helminthology SAS, Košice, Slovakia, 148 pp. (In Slovak)

GiBson, D.I., Bray, R.A., Harris, E.A. (2005): Host-Parasite database of the Natural History Museum, London. Retrieved November 26, 2019 from http://www.nhm.ac.uk/research-curation/ projects/host-parasites/

Gomez-Puerta, L.A., Valdivia-Carrera, C.A. (2018): Hymenolepis microstoma (Cestoda: Hymenolepididae) in house mice (Mus musculus) from Lima, Peru. Rev. Peru Biol., 25(3): 311 - 314. DOI:10.15381/rpb.v25i3.15213

GoodALL, R.I. (1972): The growth of Hymenolepis microstoma in the laboratory rat. Parasitology, 65(1): 137 - 142. DOI: 10.1017/ s0031182000044309

Hanzelová, V., RYšavÝ, B., Šnábel, V. (1995): Synopsis of cestodes in Slovakia III. Cyclophyllidea: Amabiliidae, Acoleidae, Catenotaeniidae, Davaineidae and Hymenolepididae (in part). Helminthologia, 32(1/2): 67 - 73

HanzelovÁ, V., RYŠAvÝ, B. (1996): Synopsis of cestodes in Slovakia IV. Hymenolepididae (continued). Helminthologia, 33(4): 213 - 222 HopkIns, C.A., Goodall, R.I., ZAJAC, A. (1977): The longevity of Hymeonlepis microstoma in mice, and its immunological cross-reaction with Hymenolepis diminuta. Parasitology, 74(2): 175 - 183. DOI: $10.1017 / S 0031182000047661$ 
Ito, A., Onitake, K., Andreassen, J. (1988): Lumen phase specific cross immunity between Hymenolepis microstoma and $H$. nana in mice. Int. J. Parasitol., 18(8): 1019 - 1027. DOI: 10.1016/00207519(88)90071-9

Jarošová, J., Antolová, D., Šnábel, V., Miklisová, D., Cavallero, S. (2020): The dwarf tapeworm Hymenolepis nana in pet rodents in Slovakia - epidemiological survey and genetic analysis. Parasitol. Res., 119: 519 - 527. DOI: 10.1007/s00436-019-06565-7

Kennedy, C.R. (1983): General Ecology. In: Arme C., Pappas P.W. (Eds) Biology of the Eucestoda, Vol. 1 Academic Press, London, p. $27-80$

Kontogiorgi, M., Opsimoulis, P., Kopterides, P., Sawa, A., Kalodimou, V.E., Belesiotou, E. Giamarellos-Bourboulis, E. (2013): Pulmonary nocardiosis in an immunocompetent patient with COPD: The role of defective innate response. Heart \& Lung, 42(4): 247 - 250. DOI: 10.1016/j.hrtlng.2013.03.007

KRIŠTOFiK, J., DANKo, Š. (2012): Mammals of Slovakia: distribution, bionomy and protection. Bratislava, VEDA, 712 pp.

Kumar, S., Stecher, G., Tamura, K. (2016): MEGA7: Molecular evolutionary genetics analysis version 7.0 for bigger datasets. Mol. Biol. Evol., 33: 1870 - 1874. DOI: 10.1093/molbev/msw054

KumarI P., Meena L.S. (2014): Factors affecting susceptibility to Mycobacterium tuberculosis: a close view of immunological defence mechanism. Appl. Biochem. Biotechnol., 174(8): 2663 - 2673. DOI: 10.1007/s12010-014-1217-3

LITCHFORD, R.G. (1963): Observations on Hymenolepis microstoma in three laboratory hosts: Mesocricetus auratus, Mus musculus, and Rattus novegicus. J. Parasitol., 49: $403-410$

LörtYnoja, A., Goldman, N. (2010): WebPRANK: a phylogeny-aware multiple sequence aligner with interactive alignment browser. BMC Bioinformatics, 11: 579. DOI: 10.1186/1471-2105$11-579$

MACNISH, M.G. (2001): Characterization of Community-Derived Hymenolepis Infections in Australia. PhD thesis. Murdoch, Australia: Division of Veterinary and Biomedical Sciences, Murdoch University, $271 \mathrm{pp}$.

Macnish, M.G., Morgan-Ryan, U.M., Monis, P.T., Behnke, J.M., THOMPSON, R.C.A. (2002): A molecular phylogeny of nuclear and mitochondrial sequences in Hymenolepis nana (Cestoda) supports the existence of a cryptic species. Parasitology, 125(Pt 6): 567 - 575. DOI: 10.1017/s0031182002002366

MaCNISH, M.G., Ryan, U.M., BehNKE, J.M., Thompson, R.C. (2003): Detection of the rodent tapeworm Rodentolepis (=Hymenolepis) microstoma in humans. A new zoonosis? Int. J. Parasitol. 33(10): 1079 - 1085. DOI: 10.1016/s0020-7519(03)00137-1

Mitchell-Jones, AJ, Bogdanowicz, W, Krystufek, B., Мitchell-Jones, A.J., Reijnders, P.J.H, Spitzenberger, F., Stubbe, C., THISSEN, J.B.M., VohraliK, V., ZIMA, J. (1999): The Atlas of European Mammals. London, UK, Academic Press, 484 pp.

МıтисH, J. (1958): Helmintofauna potkana severného na Slovensku [Helminth fauna of brown rat in Slovakia]. Final report. Institute of Helminthology SAS, Košice, Slovakia, 74 pp. (In Slovak)
Mıтuch, J. (1961): Helmintofauna hmyzožravcov a jej ekologicko geografická analýza [Helminth fauna of insectivores and its ecological - geographical analysis]. Final report. Institute of Helminthology SAS, Košice, Slovakia, 113 pp. (In Slovak)

Mıтuch, J. (1970): Helmintofauna drobných cicavcov a mäsožravcov TANAP [Helminth fauna of small mammals and carnivores, TANAP]. Final report. Institute of Helminthology SAS, Košice, Slovakia, 145 pp. (In Slovak)

Mituch, J., Hovorka, J., Hovorka, I., TenKÁČová, I. (1987): Helminty a helmintózy drobných cicavcov Karpatského oblúka) [Helminths and helminthocenoses of small mammals of Carpathian arc]. Final report. Institute of Helminthology SAS, Košice, Slovakia, 93 pp. (In Slovak)

Mohamed, S.A., Fahmy, A.S., Mohamed, T.M., Hamdy, S.M. (2005): Urea cycle of Fasciola gigantica: purification and characterization of arginase. Comp. Biochem. Physiol. B Biochem. Mol. Biol., 142(3): 308 - 316. DOI: 10.1016/j.cbpb.2005.08.002

Окаmoto, M., Agatsuma, T., Kurosawa, T., Ito, A. (1997): Phylogenetic relationships of three hymenolepidid species inferred from nuclear ribosomal and mitochondrial DNA sequences. Parasitology, 115(Pt 6): $661-666$

Olson, P.D., Yoder, K., Fajardo, L.-G. L.F., Marty, A.M., van de Pas, S., Olivier, C., Relman, D.A., 2003. Lethal invasive cestodiasis in immunosuppressed patients. J. Infect. Dis., 187(12): 1962 - 1966. DOI: 10.1086/375357

Peniche, G., Olson, P.D., Bennett, D.J., Wong, L., Sainsbury, A.W., DurRant, C. (2017): Protecting Free-Living Dormice: Molecular Identification of Cestode Parasites in Captive Dormice (Muscardinus avellanarius) Destined for Reintroduction. Ecohealth, 14(Suppl 1): 106 - 116. DOI: 10.1007/s10393-016-1108-x

Riebold, D., Russow, K., Schlegel, M., Wollny, T., Thiel, J., Freise, J., Hüppop, O., Eccard, J.A., Plenge-Bönig, A., Loebermann, M., UlRich, R.G., Klammt, S., Mettenleiter, T.C., Reisinger, E.C. (2019): Occurrence of Gastrointestinal Parasites in Small Mammals from Germany. Vector Borne Zoonotic Dis., (in press). DOI: 10.1089/ vbz.2019.2457

RYCHLIK, L. (2000): Habitat preferences of four sympatric species of shrews. Acta Theriol., 45(Suppl. 1): $173-190$

Schantz, P.M. (1996): Tapeworms (cestodiasis). Gastroenterol. Clin. North. Am., 25(3): 637-653.

ScHMIDT, G.D. (1986): Handbook of Tapeworm Identification. Boca Raton, FL, CRC Press, $688 \mathrm{pp}$.

Sharma, S., LYNGdoh, D., RoY, B., TANDon, V. (2016): Differential diagnosis and molecular characterization of Hymenolepis nana and Hymenolepis diminuta (Cestoda: Cyclophyllidea: Hymenolepididae) based on nuclear rDNA ITS2 gene marker. Parasitol. Res., 115(11): 4293 - 4298. DOI: 10.1007/s00436-016-5210-3

Sievers, F., Wilm, A., Dineen, D.G., Gibson, T.J., Karplus, K., LI, W., Lopez, R., McWilliam, H., Remmert, M., Söding, J., Thompson, J.D., HIGGINS, D.G. (2011): Fast, scalable generation of high-quality protein multiple sequence alignments using Clustal Omega. Mol. Syst. Biol., 7: 539. DOI: 10.1038/msb.2011.75 
SkRJabin, K.I., Kalantarian, E.V. (1942): Continuation to the biology of the cestode Hymenolepis straminea (Goeze, 1882) parasitic of hamster. Comptes Rendus Acad. Sci. URSS, 36, 222 - 223

SMYTH, J.D., WAKELIN, D. (1994): Introduction to Animal Parasitology. Cambridge, Cambridge University Press, 549 pp.

SPASSKII, A.A. (1954): [Classification of Hymenolepididae from mammals]. Tr. Gel'mintol Lab., 7: 120 - 167 (In Russian)

TAMURA, K. (1992): Estimation of the number of nucleotide substitutions when there are strong transition-transversion and $\mathrm{G}+\mathrm{C}$-content biases. Mol. Biol. Evol., 9: 678 - 687. DOI: 10.1093/oxfordjournals.molbev.a040752

Tielens, A.G.M., van Hellemond, J.J. (2006): Unusual Aspects of Metabolism in Flatworm Parasites. In: Maule, A.G., Marks, N.J. (Eds) Parasitic Flatworms: Molecular Biology, Biochemistry, Immu- nology and Physiology. Belfast, UK: Queen's University Belfast, pp. $387-407$

Tsal, I.J., Zarowiecki, M., Holroyd, N., Garciarrubio, A., Sanches FLoRES, A., BRooks, K.L., ET AL. (2013): The genomes of four tapeworm species reveal adaptations to parasitism. Nature, 496(7443): 57 - 63. DOI: 10.1038/nature12031

VoGE, M. (1964): Development of Hymenolepis microstoma (Cestoda: Cyclophyllidea) in the intermediate host Tribolium confusum. Parasitology, 50: 77 - 80

Whary, M.T., Baumgarth, N., Fox, J.G., Barthold, S.W. (2015): Biology and diseases of mice. In: Fox, J, Anderson, L, Otto, G, PritchetT-Corning, K, Whary, M. (Eds) Laboratory animal medicine. $3^{\text {rd }}$ Edition, New York, NY: Academic Press, pp. $124-125$ 